\title{
Między konfliktem a wspólistnieniem. Stosunki hindusko-muzułmańskie na wybranych obszarach wiejskich w północno-zachodnich Indiach
}

\begin{abstract}
Przedmiotem sporu pomiędzy hinduskimi nacjonalistami a zwolennikami tzw. synkretycznej wizji indyjskiej cywilizacji jest dziś kwestia, czy muzułmanów można uważać za jej równoprawnych współtwórców. Obok przedstawionego pytania o historyczne uzasadnienie obecności muzułmanów w dzisiejszych Indiach, istnieje także problem ich własnej tożsamości i poczucia odrębności od hindusów. Z tego powodu islam, druga co do wielkości religia w Indiach, jest często przeciwstawiana hinduizmowi jako „element obcy" $(. . .)^{1}$.
\end{abstract}

\section{Wstęp}

Społeczno-polityczne relacje między indyjskimi muzułmanami a hindusami stanowią zjawisko tyleż fascynujące, co złożone. Niniejszy artykuł porusza tę mało znaną na polskim rynku wydawniczym tematykę, stanowiąc istotne rozszerzenie dotychczasowych badań w zakresie stosunków hindusko-muzułmańskich. Celem artykułu jest przybliżenie genezy konfliktu hindusko-muzułmańskiego oraz analiza stereotypów i postaw względem muzułmanów. Artykuł został oparty na badaniach terenowych przeprowadzonych w wybranych wioskach północnoindyjskich w styczniu i lutym 2018 roku. Oferuje wnikliwe spojrzenie na te relacje w optyce mieszkańców wybranych indyjskich wiosek, co stanowi o oryginalności przeprowadzonych badań.

1 K. Osuchowska, Relacje hindusko-muzutmańskie w wielokulturowym społeczeństwie indyjskim, „Wschodnioznawstwo” 2013, nr 7, s. 110. 


\section{Rys historyczny}

Islam przybył do Azji Południowej najpierw jako religia, dopiero później jako siła polityczna. Zwycięstwo Umajjadów nad prowincją Sindh przez Muhammada Ibn al-Qāsima w latach $711-715^{2}$ skutkowało kolejnymi podbojami, w tym najazdem na Indie dokonanego przez Mahmūda Ghaznawiego (999-1026), niosącymi za sobą masowe konwersje na islam ${ }^{3}$, rozkwit księstwa Ghor ${ }^{4}$, ustanowienie Sułtanatu Delhijskiego ${ }^{5}$, a następnie Imperium Wielkich Mogołów w roku 1526.

Islam jest drugą po hinduizmie, najczęściej praktykowaną religią w Indiach. 172 mln, czyli 14,2\% społeczeństwa Indii, stanowią dziś muzułmanie $^{6}$. Jednakże nieoficjalne źródła donoszą o wielkości rzędu nawet $20-30 \%$ populacji. Jest to aktualnie trzecia, po Indonezji i Pakistanie, najbardziej liczna grupa wyznawców islamu na świecie. Muzułmanie są większością na Lakșadvīp (95\%) oraz w stanie Jammū aur Kaśmīr, gdzie stanowią ponad $67 \%$ ludności ${ }^{7}$ Jednak największa liczba muzułmanów skupia się w najludniejszym indyjskim stanie Uttar Pradeś, gdzie zamieszkuje ich około 31 mln, co stanowi około 18,7\% wszystkich mieszkańców. Znaczna część muzułmanów indyjskich zamieszkuje również Paścim Baṁgāl [pol. Bengal Zachodni], Bihār oraz Mahārāștrę. Mieszka w nich łącznie ponad 30 mln muzułmanów. Keralę, Āṇdhra Pradeś, Asam, Jammū aur Kaśmīr oraz Karnāțakę zamieszkuje od 5 do 10 mln wyznawców islamu, zaś Rājasthān, Gujarāt, Madhja Pradeś, Jhāṛkhaṇ̣ i Tamil Nāḍu od 3 do 5 mln. W Delhi, Hariyānāā, Uttarākhaṇụ tą liczbę szacuje się na 1-2 mln. Znamiennym

2 A. Berzin, Part I: The Umayyad Caliphate (661-750 CE), The First Muslim Incursion into the Indian Subcontinent, The Historical Interaction between the Buddhist and Islamic Cultures before the Mongol Empire, https://studybuddhism.com/en/advanced-studies/history-culture/ buddhism-islam-advanced/buddhist-muslim-interaction-umayyad-caliphate/first-muslim-incursion-into-the-indian-subcontinent\#n5 [dostęp: 10.04.2018].

3 J. McLeod, The history of India, Westport 2002, s. 34.

4 S. Chandra, Medieval India from Sultanat to Mughals: 1206-1526 Part 1, 1997, s. 22.

5 A. Schimmel, Islam in the Indian Subcontinent, Leiden, 1980.

6 Religion Data - Population of Hindu / Muslim / Sikh / Christian - Census 2011 India, www.census2011.co.in [dostęp: 10.04.2018].

7 J. Zajączkowski, Indie w stosunkach międzynarodowych, Warszawa 2007, s. 83. 
jest, iż wszystkie duże stany zamieszkiwane są przez znaczną mniejszość muzułmańską. Jedynie w stanach takich jak Paṇjāb i Oṛiśā żyje ich mniej niż milion. Spośród 593 indyjskich dystryktów tylko 20 jest zamieszkiwanych w większości przez muzułmanów. W sumie, w dystryktach o większości muzułmańskiej mieszka 18 mln wyznawców islamu, co stanowi 13\% spośród wszystkich mieszkających w Indiach. Pozostali stanowią w swoim otoczeniu mniejszość ${ }^{8}$. Muzułmanie znani są również w historii Indii jako prominentne osoby publiczne i politycy, którym wielokulturowość umożliwiła rozwój i awans społeczny. Spośród 13 indyjskich prezydentów, aż trzech wywodziło się ze społeczności muzułmańskiej'. Bodaj jednym z najpopularniejszych indyjskich muzułmanów był „A.P.J”. Abdul Kalam.

Temat stosunków hindusko-muzułmańskich jest stale obecny w dyskursie politycznym we współczesnych Indiach. Stanowi oręż gry politycznej wykorzystywany przez polityków reprezentujących zantagonizowane społeczności. Nieprzychylny muzułmanom obóz powołujący się na ideologię hindutvy ${ }^{10}$ często podnosi, iż niekontrolowany wzrost ludności muzułmańskiej w Indiach jest w istocie celowym zabiegiem stanowiącym potężne zagrożenie dla Indii i ich oryginalnie hinduskiego charakteru. $\mathrm{Z}$ kolei frakcje pro-muzułmańskie sięgają po argument swej licznej populacji, aby zwiększyć morale społeczności postrzeganej jako słabsza, często dyskryminowanej zarówno ekonomicznie, społecznie, jak i politycznie. Ideolodzy hindutvy dezawuują zasady obecne w indyjskiej Konstytucji, suponując, iż oficjalna laickość państwa to negowanie wielowiekowego dorobku hinduizmu, na którego zrębach powinno być zbudowane współczesne państwo. To hindusi stanowią bowiem absolutną większość indyjskiego społeczeństwa ${ }^{11}$.

8 Prime Minister's High Level Committee Cabinet Secretariat Government of India Social, Economic and Educational Status of the Muslim Community of India, November 2006, s. 29-30, http://iamc.com/reports/2006/pmhlc.muslims.pdf [dostęp: 20.07.2018].

9 J. Zajączkowski, op.cit., s. 83-85.

10 Termin hindutva (hindi हनिद्युत्व) oznacza „hinduskość”. W ten sposób określa się hinduski nacjonalizm - polityczną ideologię, która w budowie tożsamości i w agitacji politycznej korzysta z tradycji religijnych.

11 B. Chakrabarty, Indian Politics and Society Since Independence, New York 2008, s. 78. 


\section{Idea dwóch narodów}

Jednym z największych projektów politycznych dotyczących obu społeczności na subkontynencie indyjskim była idea dwóch narodów (ang. two-nation theory). Miała ona swój początek jeszcze w epoce Indii Brytyjskich (ang. British Raj), gdy rozwijał się ruch narodowy postulujący uzyskanie przez Indie pełnej suwerenności. Liczba muzułmanów w ówczesnym społeczeństwie indyjskim oscylowała wokół 100 milionów, spośród których znakomita większość wspierała działania Ligi Muzułmańskiej. Jej nadrzędnym celem było utworzenie osobnego państwa o charakterze muzułmańskim. Muhammad 'Alī Jinnāḥ ${ }^{12}$ czerpał z idei dwóch narodów, która była odpowiedzią na obawy społeczności muzułmańskiej wobec hinduskiej hegemonii. W przemówieniu wygłoszonym w 1940 roku w Lahore Jinnāḥ mówił:

„(...) Niezwykle trudno jest pojąć, dlaczego nasi hinduscy przyjaciele nie potrafią zrozumieć prawdziwej natury islamu i hinduizmu. Hindusi i muzułmanie (...) nie żenią się między sobą, nie jadają razem i w rzeczywistości przynależą do dwóch odrębnych cywilizacji, które opierają się na przeciwstawnych ideach i koncepcjach (...). Połączenie dwóch takich narodów w ramach jednego państwa i postawienie jednego z nich w roli większości, drugiego zaś w roli mniejszości, musi doprowadzić do wzrastającego niezadowolenia i ostatecznie destrukcji każdej struktury rządowej, jaką można by zbudować w takim państwie $(\ldots)^{13}$.

Podsycanie konfliktu nierzadko przypisuje się również brytyjskim kolonizatorom, którzy w napięciach pomiędzy muzułmanami a hindusami upatrywali szansy na osłabienie ruchu narodowego i usprawiedliwienie swej obecności w Indiach. Przedstawiciele indyjskiego ruchu narodowego dostrzegali w polityce imperialnej stosowanie starej zasady divide et impera $^{14}$. Brytyjczycy zazwyczaj aprobowali te żądania muzułmanów, które

12 Indyjski i pakistański polityk, jeden z twórców państwowości pakistańskiej. Znany jest także jako Wielki Prowadzący (urdu قائد اعظم) lub Ojciec Narodu (urdu بابائح قوم).

13 Przemówienie Muhammada 'Alego Jinnāḥa na zjeździe Ligi Muzułmańskiej, Lahore 1940, tłum. własne, http://www.columbia.edu/itc/mealac/pritchett/00islamlinks/txt_jinnah_ lahore_1940.html [dostęp: 24.07.2018].

14 G.R. Thursby, Hindu-Muslim Relations in British India: A Study of Controversy, Con- 
mogły skutkować osłabieniem Partii Kongresowej - największej siły politycznej Indii partycypującej w ruchu niepodległościowym. Faworyzowano zatem Ligę Muzułmańską, a następnie ideę utworzenia dwóch osobnych państw, licząc na współpracę z liderem indyjskich muzułmanów Muhammadem 'Alīm Jinnāḥem. Nowa granica indyjsko-pakistańska stała się areną krwawych zamieszek, które pochłonęły około miliona ofiar. W wyniku potężnego exodusu ludności muzułmańskiej do Pakistanu oraz ludności hinduskiej do Indii miejsce zamieszkania zmieniło około $10 \mathrm{mln}$ osób, co pociągało za sobą dramatyczne losy uchodźców, którzy po opuszczeniu swych domów, nierzadko pozostawali bez środków do życia ${ }^{15}$. Podział Indii stał się przyczyną jednej z największych i najbardziej gwałtownych migracji w historii ludzkości. Towarzyszyły mu liczne pogromy (źródła podają liczbę zaginionych sięgającą 3,4 mln, napływ ludności rzędu 14,5 mln oraz odpływ wynoszący $17,9 \mathrm{mln}^{16}$ ). Indie stały się wówczas polem walk, rywalizacji i zamieszek na tle hindusko-muzułmańskim.

Od momentu powstania Pakistanu w 1947 roku i Bangladeszu w roku 1971 muzułmanie mieli do dyspozycji dwa państwa położone na dwóch przeciwległych końcach Indii Brytyjskich, a jako mniejszość zostali rozproszeni na całym terytorium Indii. Utworzenie Bangladeszu uzmysłowiło jednak, że sama religia nie stanowi wystarczającego spoiwa dla powoli konsolidującej się państwowości indyjskich muzułmanów ${ }^{17}$. Idea odseparowania od siebie społeczności hinduskiej i muzułmańskiej okazała się chybiona. Pozostała w Indiach liczna mniejszość muzułmańska liczyła wówczas około $35 \mathrm{mln}$. Zdecydowanej większości z nich nie było stać na migrację, inni z kolei nie identyfikowali się z koncepcją dwóch narodów ${ }^{18}$.

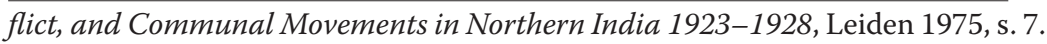

15 P. Lament, M. Zobeniak, Indie - Pakistan - Kaszmir, [w:] Indie w XXI wieku, wybrane problemy, red. A. Potyrała, M. Skobrtala, Poznań 2009, s. 162.

16 P. Bharadwaj, A. Khwaja, A. Mian, The Big March: Migratory Flows after the Partition of India, [w:] Economic \& Political Weekly: 43, s. 1, https://sites.hks.harvard.edu/fs/akhwaja/ papers/Big\%20March\%20EPW\%20Publish08.pdf [dostęp:10.04.2018].

17 K. Osuchowska, op.cit., s. 112.

18 B. Rao, Between Promises and Performance. A Critique of Nehru's Contribution to Secularismin India, „Journal of Asian and African Studies” 2006, Vol. 41 (4), s. 367. 


\section{Konflikt hindusko-muzułmański. Polityka i komunalizm}

Obie strony konfliktu posiadały swoją reprezentację polityczną. Wspomniany termin hindutva został ukuty i spopularyzowany przez Vināyaka Dāmodara Sāvarkara i pochodzi z dzieła wydanego w 1923 roku, pt. Hindutva: Who is a Hindu? Hindutva stała się podstawą programową radykalnej organizacji Narodowego Stowarzyszenia Ochotnikow (trl. Rāṣtriya Svayamsevak Sangh) w skrócie RSS ${ }^{19}$ oraz Hindū Mahāsabhā powołujących się na nacjonalistyczną ideologię „Indii dla hindusów” oraz ideę „militaryzacji hinduizmu" ${ }^{20}$. Warto zauważyć, iż odwoływanie się hinduskich nacjonalistów do idei wykluczania innowierców ze społeczeństwa, kontestacja państwa świeckiego czy militaryzacja polityki, nie stanowią obcej tkanki w tradycji hinduizmu. Thomas Schweer określił to zjawisko mianem „formalnej tolerancji ${ }^{21}$ ”. Nacjonalizm indyjski jest zjawiskiem o dość dawnej proweniencji. Sięga przełomu XIX i XX wieku, gdy powstawał reformatorski ruch $\bar{A} r y a$ Samāj oraz prawicowa partia broniąca interesu hinduskiego, wspomniana Hindū Mahāsabhā, powołana do życia w roku 1914 w odpowiedzi na powstanie Ligi Muzułmańskiej. Ta największa z partii politycznych zrzeszających wyznawców islamu walczyła o interesy społeczności muzułmańskiej w Indiach, a także o utworzenie oddzielnego państwa muzułmańskiego Pakistan ${ }^{22}$.

Wszystkie nacjonalistyczne ruchy polityczne były wówczas napędzane przez ideologie zbudowane na prymacie własnej religii i niedopuszczaniu do głosu pozostałych. Ukute zostało nawet eufemistyczne pojęcie „kulturowego nacjonalizmu"23.

Przed Podziałem Indii (ang. Partition ${ }^{24}$ ) Mahātmā Gaṃdhī opisywał

19 Na temat RSS zob.: W.K. Andersen, S.D. Damle, The Brotherhood in Saffron: The Rashtriya Svayamsevak Sangh and Hindu Revivalism, Boulder 1987.

20 V. Ramakrishnan, A legacy of duplicity, "Frontline" 2006, Vol. 23, s. 14-27.

21 T. Schweer, Hinduizm. Powstanie-dzieje-nauka, Warszawa 2003, s. 90-91.

22 P. Hardy, The Muslims of British India, Cambridge: Cambridge University Press, 1972.

23 S.S. Khan and R. Sen, Where Are We Going? Perspective on Hindu-Muslim Relations in India, [w:] Peace Psychology in Asia, red. N. Noor, C.J. Montiel, 2009, s. 45.

24. Podział Indii Brytyjskich (ang. Partition) na dominia Indie oraz Pakistan, a także podział stanów Asam, Bamigāl i Paṇjāb dokonany w 1947 r. Linię demarkacyjną pomiędzy Indiami a Pakistanem nazwano Linią Radcliffe'a. 
napięcia w relacjach hindusko-muzułmańskich jako „problem problemów" (ang. the problem of problems) ${ }^{25}$. Próbując łagodzić spory, w styczniu 1948 roku został zamordowany z rąk gorliwego wyznawcy hinduizmu. Sprawca, Nathurām Goḍse - entuzjasta nacjonalistycznej wykładni hindutvy dopuścił się zabójstwa - ponieważ wierzył, iż łagodność i pokojowa strategia Gandhiego wobec indyjskiego islamu to wyraz zdrady hinduskiej racji stanu. Od samego początku organizacja RSS usiłowała zdeprecjonować dziedzictwo myśli Gandhiego o Indiach jako domu dla wielu współistniejących ze sobą religii ${ }^{26}$. Wiele środowisk potępiało jego działalność na rzecz promocji sekularyzmu oraz próbę budowania mostów pomiędzy religiami.

Zarówno w rządzie, jak i w całej partii Indyjskiego Kongresu Narodowego obecni byli politycy o skrajnych poglądach inspirowanych ideologią hindutvy. W najludniejszym stanie Uttar Pradeś, którym rządził Govind Ballabh Pant, zamknięto mniejszościom drogę do posad rządowych oraz policji, a także pozbawiono finansowania szkoły nauczające w języku urdu. Pomimo sprzeciwu Javāharlāla Nehrū, eskalacji nastrojów antymuzułmańskich trudno było zapobiec. Według historyka Mushirula Hasana, gros muzułmanów, którzy pozostali w Indiach wierzyła jednak w ideę laickości państwa i to w nim upatrywała swojej przyszłości ${ }^{27}$. Istotnym wydaje się również, iż mniejszość muzułmańska została pozbawiona silnego przywództwa, ponieważ szereg liderów zaangażowanych i oddanych sprawie muzułmańskiej wkrótce emigrowało do Pakistanu ${ }^{28}$. Do najbardziej liczących się islamskich organizacji politycznych należały Jam'iyat Ulama-i Hind (urdu جمعيت علمائح بند), oraz Jama'at-i Islami (urdu جماعتِ اسلامى). Jami’yat współpracowała ściśle z Kongresem i utożsamiała się z sekularyzmem i ideą „złożonego narodu ${ }^{29}$ ”. Jama’at zaś ewoluowała w kierunku organizacji skrajnej, była zdecydowanie przeciwna reformom społecznym

25 A.K. Singh, Intergroup relations and social tensions, [w:] Psychology in India: The stateof-the-art, red. J. Pandey, Vol. 2, 1989, s. 159-223.

26 T. Basu, P. Datta, S. Sarkar, T. Sarkar, S. Sen, Khaki shorts saffron flags, New Delhi: Orient Longman, 1993.

27 M. Hasan, Adjustment and Accommodation: Indian Muslims after Partition, "Social Scientist" 1990, Vol. 18, No. 8/9, s. 52-53.

28 B. Rao, op.cit., s. 379.

29 K. Osuchowska, op.cit., s. 113. 
i wkrótce ruch ten emigrował do Pakistanu. Społeczność muzułmańską cechowały liczne podziały, a poszczególne organizacje polityczne obierały rozmaite, nierzadko rozbieżne ze sobą cele, co nie sprzyjało współpracy zarówno na poziomie lokalnym, jak i krajowym. W rezultacie większość muzułmanów była wyborcami Kongresu pod przewodnictwem Nehrū ${ }^{30}$. Dopiero od momentu wprowadzenia stanu wyjątkowego w 1975 roku przez Indirę Ga'dhī nastąpił znaczący odpływ wyborców muzułmańskich na rzecz partii lokalnych ${ }^{31}$. Obecnie muzułmanie wciąż pozostają rozproszeni i nie istnieje jedna organizacja reprezentująca ich interesy. Wynika to również ze zróżnicowania regionalnego, bowiem w zależności od miejsca zamieszkania posługują się innymi językami, a zarówno ich problemy, jak i potrzeby są różne ${ }^{32}$.

\section{Konflikt w mieście Ajodhja}

Kością niezgody pomiędzy społecznościami hinduską i muzułmańską oraz siłą napędzającą konflikt nieustannie inspirowany przez obóz hindutvy, jest kazus meczetu Babri Masjid (urdu بابرى مسجد) w mieście Ajodhja, przez hindusów określany mianem Ram Janambhoomi (hindi राम जन्मभूमि), czyli miejsca narodzin boga Ramy. Do dziś obie grupy religijne roszczą sobie do niego prawa. Wedle narracji hinduskiej w tym miejscu znajdowała się świątynia Ramy zburzona przez muzułmanów w XVI wieku. W 1528 roku powstał w tym miejscu meczet. W 1986 roku lokalny sąd wydał wyrok zezwalający ludności hinduskiej na odprawianie ceremonii i rytuałów religijnych w meczecie Babri Masjid. Wywołało to poważne napięcia na tle religijnym zarówno w Indiach, jak i w krajach ościennych (np. Pakistan, Bangladesz). W 1990 roku oraz 6 grudnia 1992 roku wybuchły kolejne krwawe zamieszki, a tysiące fanatyków hinduistycznych z ruchu Kār Sevaks ${ }^{33}$ zburzyło meczet, aby zbudować na jego miejscu hinduistycz-

\footnotetext{
30 B. Rao, ibidem, s. 380.

31 J. Zajączkowski, op.cit, s. 85.

32 K. Osuchowska, op.cit., s. 114.

33 Kār Sevaks (sanskr. सेवा trl. sevā - selfless service) - Grupa o charakterze hinduistycznym oferująca swą pracę nieodpłatnie w imię religii. Zainspirowani przez nacjonalistyczną organizację Viśva Hindū Parișada do odbudowy świątyni Ramy w Ajodhji, doprowadzili do zniszczenia meczetu Babri.
} 
ny kompleks świątynny. Doszło wówczas do masowych pogromów ludności muzułmańskiej zarówno w mieście, jak i na terenie całych Indii ${ }^{34}$. Zamieszki te pochłonęły ponad 200 tys. osób, a około 100 tys. musiało poddać się przymusowej migracjii ${ }^{35}$. W 2010 roku mocą wyroku indyjskiego sądu, podzielono sporne terytorium Ajodhji między obie społeczności, a w 2011 roku skazano na śmierć 11 osób, uznanych za winnych podpalenia pociągu Sabarmati Express w 2002 roku, spośród których znaczną część ofiar stanowili działacze hinduisyczni wywodzący się ze wspomnianego już ruchu Kār Sevaks powracający z miejsca kultu w Ajodhji.

Rządowy raport „Social Economic and Educational Status of the Muslim Community of India" z 2006 r. (tzw. raport Sachara) nie pozostawił złudzeń o ekonomicznym i społecznym zacofaniu społeczności muzułmańskiej. Odzwierciedlenie niekorzystnej sytuacji muzułmanów we współczesnych Indiach stanowi także film Kolor Szafranu ${ }^{36}$. Młody muzułmanin o imieniu Aslan wraz ze swoimi hinduskimi przyjaciółmi cieszącymi się wyższą pozycją społeczną, bierze udział w protestach ulicznych przeciwko korupcji. Wzbudza tym gniew ojca, który oczekuje od Aslana większej odpowiedzialności, a zarazem powściągliwości w podejmowaniu takich inicjatyw. Wynika to ze znacznie trudniejszej sytuacji muzułmanów w Indiach, którzy w przypadku schwytania przez policję, mogliby zostać potraktowani z większą brutalnością bez poszanowania prawa.

Do dnia dzisiejszego muzułmanie i hindusi nie cieszą się równością wobec prawa. Jak podaje P. Anderson:

„Jedna czwarta ich dzieci między 6 a 14 rokiem życia nie chodzi do szkoły. Na stu absolwentów 50 najlepszych szkół wyższych tylko dwóch jest muzułmanami. W przypadku elitarnych ośrodków technologicznych - czterech na stu. W miastach muzułmanie mają mniejsze szanse na znalezienie pracy niż dalici czy adivasi" ${ }^{\prime 3}$.

34 C. Jaffrelot, The Hindu Nationalist Movement and Indian Politics, 1996, s. 420-431, $455-457$.

35 “Time”, 15.02.2003.

36

Rang De Basanti , reż. Rakeysh Omprakash Mehra, Indie 2006.

37 P. Anderson, After Nehru, "London Review of Books" 2012, 34:15, s. 21-36. 
Dziennik „Hindustan Times” podaje szereg zamieszek hindusko-muzułmańskich od czasu uzyskania niepodległości ${ }^{38}$ :

- w Ahmedabadzie w 1969 roku (około 1000 ofiar)

- w Merrut w 1987 roku (około 350 ofiar)

- w Bahagalpur w 1989 roku (około 1000 ofiar)

- w Bombaju w 1992 roku (około 1800 ofiar)

- w Gudźaracie w 2011 roku (58 ofiar)

Zarzewia konfliktów religijnych należy doszukiwać się w wysoce konfliktogennej obecnej polityce indyjskiej. Nabierają one tempa głównie podczas wyborów oraz świąt religijnych i towarzyszących im procesji. Prowadzą do licznych zamieszek, za które odpowiedzialność ponoszą politycy wykorzystujący je do swych partykularnych celów politycznych. Przykładem może być wizyta Bala Saheb Deorasa w mieście Jamshedpur w stanie Jhāṛkhaṇ na początku kwietnia 1979 roku, podczas której lider RSS „zachęcał hindusów do walki o swoje prawa w hinduskim kraju. Dziesięć dni później miasto stanęło w płomieniach" ${ }^{39}$. Próba wyeliminowania religii ze sfery publicznej Indii nie została zatem urzeczywistniona. Politycy indyjscy, przed podjęciem kluczowych decyzji dla kraju, w dalszym ciągu korzystają z usług numerologów, a obecność rytuałów i ceremonii religijnych jest wszechobecna nawet na najwyższych szczeblach władzy.

\section{Badania terenowe}

Celem badań terenowych było określenie, jakie nastroje panują w społeczności hinduskiej i muzułmańskiej we współczesnej indyjskiej wiosce oraz jakie postawy i stereotypy występują wśród hindusów tam żyjących. Badanie zostało przeprowadzone w 2018 roku podczas stażu studyjno-badawczego w Indiach, we wsi Kokamthāṇ. Wzięło w nim udział ponad 40 respondentów - mieszkańców trzech okolicznych wiosek. Były to osoby obu płci, w wieku od 18 do 64 lat, z którymi wywiady prowadzone były $\mathrm{w}$ ich domach lub miejscach pracy podczas kilku sesji. Badani wybierani

38 PTI, Chronology of Communal Violence, "Hindustan Times", 9.11.2011, https://www. hindustantimes.com/india/chronology-of-communal-violence-in-india/story-jJtcgvxFYh5N3jhSw7H4KN.html [dostęp: 24.07.2018].

39 M.J. Akbar, Riot after Riot. Reports on Caste and Communal Violence in India, New Delhi 2003, s. 15. 
byli przy pomocy techniki kuli śnieżnej, gdzie to sami ankietowani typują kolejnych potencjalnych respondentów.

W badaniu zastosowano metody jakościowe takie jak obserwacje, wywiady oraz kwestionariusze. Ankietowani byli pytani o swą przynależność kastowo-warnową ${ }^{40}$. Kwestionariusze oraz wywiady prowadzone były zarówno w języku angielskim, jak i w języku hindi oraz urdu. Pytania zostały skonstruowane w sposób umożliwiający poznanie rozmaitych postaw wobec ludności muzułmańskiej w Indiach. W centrum mojej uwagi znalazły się doświadczenia hindusko-muzułmańskie, stereotypy i skojarzenia oraz stan wiedzy na temat mniejszości muzułmańskiej wśród hinduskich mieszkańców wsi. Badani pytani byli o liczbę muzułmanów zarówno w całych Indiach, jak i w poszczególnych miejscach zamieszkania (wieś Kokamthāṇ, Kopergã̃v i Śirdī), skojarzenia wobec islamu, znajomość religii i tradycji muzułmańskich oraz tradycyjne zawody wykonywane przez indyjskich muzułmanów. Respondenci hinduscy przytaczali swe codzienne doświadczenia z ludnością muzułmańską, muzułmanie zaś opisywali jak współcześnie zarysowują się relacje hindusko-muzułmańskie w okolicy miejsca ich zamieszkania. Główne pytanie odnosiło się do tego, czy zauważają trudne do pogodzenia cechy i zwyczaje odróżniające od siebie obie badane społeczności. Na zakończenie ankiety respondenci pytani byli o swój pogląd dotyczący rodzin mieszanych i potencjalną akceptację muzułmańskiego członka rodziny.

Przeprowadzone badania wskazują, iż wprawdzie różnice pomiędzy obiema społecznościami są znaczące, a obie grupy konsekwentnie dążą do zachowania odrębności, ale na poziomie indyjskiej wsi można mówić raczej o dążeniu do współistnienia i współdziałania, aniżeli konfliktu. Ten jest dziś szczególnie łatwy do wychwycenia na niwie indyjskiej polityki nierzadko celowo antagonizującej obie grupy w celu zgromadzenia więk-

40 Powszechnie znany jest fakt, iż kasty funkcjonują wśród nie-hindusów w Indiach, choć stan wiedzy na ten temat pozostaje niewielki, jak podkreślał czołowy francuski antropolog, badacz kastowości Louis Dumont w książce Homo Hierarchicus. W społeczeństwie indyjskim system warnowo-kastowy pełni rolę włączającą oraz integrującą pozostałe grupy religijne. Na subkontynencie istotnie oddziałuje on na społeczności zarówno chrześcijan, jak i muzułmanów i jest wśród nich replikowany. O tym, że kasty funkcjonują w regionie poza społecznościami hindusów, a nawet poza granicami Indii, świadczy choćby fakt, że w Pakistanie żyje około 3 mln niedotykalnych (A. Nitza, Kulturowo-społeczna specyfika Indii i Pakistanu a demokracja, [w:] Azja, Afryka: Inność - Odmienność - Różnorodność, red. P. Bachtin, M. Klimiuk, Warszawa 2014, s. 164). 
szego kapitału politycznego. Zdecydowana większość badanych przeze mnie respondentów odrzuca zasadność tego konfliktu. Przykładem może być wywodzący się ze społeczności hinduskiej 40-letni Rahul, którego zdaniem:

„Indie powinny stanowić i stanowią dom dla wielu wyznań i żadne z nich nie powinno mieć prawa do supremacji. Co więcej, konflikty te mają współcześnie tło polityczne i są celowo nakręcane przez polityków, co nie służy ani społeczności hinduskiej, ani muzułmańskiej. Jest to de facto ze szkodą dla wszystkich".

Wszyscy badani potrafili wskazać przynajmniej kilku przyjaciół rodziny, kolegów z pracy lub zatrudnionych w swojej firmie pracowników wywodzących się ze społeczności muzułmańskiej. Wszyscy badani przeze mnie hinduscy pracodawcy wypowiadali się o nich z najwyższym szacunkiem i aprobatą. 36-letni Pankaj zatrudniający muzułmanina w swoim sklepie bardzo chwali sobie jego lojalność i oddanie. Przekonuje, że zarówno on, jak i jego otoczenie jest zgodne, iż:

„Muzułmanie to dobrzy ludzie, dobrzy sąsiedzi i przyjaciele. Sam chętniej zatrudniłem młodego muzułmańskiego chłopca ze względu na jego motywację do ciężkiej, ale uczciwej pracy. Wielu moich znajomych z branży handlowej ma podobne zdanie. Z mojego doświadczenia muzułmanie to uczciwi ludzie, choć nasza kultura, religia i mentalność często znacznie się od siebie różni”.

Ponad $80 \%$ badanych nie wyobraża sobie jednak muzułmanina w roli członka rodziny. 32-letnia lekarka urodzona w rodzinie braminów nie wyobraża sobie, że taki mezalians w hinduskiej rodzinie mógłby zostać zaakceptowany:

„Nie mam nic przeciwko muzułmanom jako takim, sama wychowałam się z moim przyjacielem Azarem Shaikh i moja rodzina traktowała go jak członka rodziny. Wspominam te lata bardzo pozytywnie i sielankowo. Jednak różnimy się. Nawyki jedzeniowe, higieniczne, rytualne to coś nie do pogodzenia w małżeństwie mieszanym".

Respondentka przytacza wątek przyjaciela-muzułmanina:

„W dzieciństwie moim najlepszym przyjacielem był muzułmanin. Mimo, że pochodzę z rodziny braminów, nasz dom był zawsze otwarty 
dla innych religii i kast. Również Azar był mile widziany o każdej porze dnia. Po szkole często chodziliśmy do świątyni hinduistycznej. Azar razem z nami brał udział w ceremonii pudży. Ani on, ani jego rodzice nie mieli nic przeciwko takiej międzykulturowej integracji. Dopiero gdy dorośliśmy, zaczęłam dostrzegać znaczące różnice między nami. Nasze nawyki żywieniowe i higieniczne były zupełnie inne. Przebywając ze sobą dość często, zauważyłam, iż zaczęła przeszkadzać mi jego niewegetariańska dieta”.

Inny respondent, który wolałby pozostać anonimowy potwierdza to stanowisko:

„Hindusi i muzułmanie potrafią żyć razem, ale żaden hindus nie zaakceptowałby w pełni muzułmanina jako członka rodziny. Rytualnie czysta dieta i zakaz spożycia wołowiny są dla społeczności hinduskiej kluczowe i nie pozostawiają miejsca na jakiekolwiek wątpliwości”.

Ze zgromadzonego przeze mnie materiału badawczego wynika również, iż obie społeczności dość dobrze rozpoznają wzajemne zwyczaje, tradycje, a także posiadają podstawową wiedzę na temat wzajemnych religii i zasad je regulujących. Wszyscy badani bez trudu wymienili namāz (w świecie arabskim znana jako as-ṣalāa), czyli obowiązkowa modlitwa odprawiana pięć razy dziennie z twarzą zwróconą w stronę Mekki, kalma (šahäda), czyli wyznanie wiary, rōzah, czyli post w miesiącu ramadan oraz hağğ (pielgrzymka do Mekki). Ponad 60\% ankietowanych hindusów regularnie obchodzi święto 'I $\bar{l}$ al-'Adḥa (święto ofiarowania) wraz ze swoimi muzułmańskimi przyjaciółmi czy sąsiadami. Podobnie muzułmanie celebrują hinduskie święto Diwāli.

Na uwagę zasługuje fakt, że respondenci zdecydowanie przeszacowywali liczbę przedstawicieli mniejszości muzułmańskiej w Indiach oraz w zamieszkiwanych przez siebie społecznościach. Trzy czwarte badanych była przekonana, iż liczba muzułmanów w Indiach jest znacznie wyższa niż w rzeczywistości. Zgodnie z ich szacunkami wskaźnik ten jest wyższy o 10-30 punktów procentowych od rzeczywistej liczby muzułmanów wynoszącej zgodnie ze spisem 2011 roku 14,2\%. Ponad połowa badanych twierdzi też, że przyrost naturalny ludności muzułmańskiej w Indiach jest niebezpieczny dla przyszłości tego kraju. 62-letni dyrektor szkoły nazywa ten przyrost galopującym, zaś 28-letni nauczyciel geografii w szkole pod- 
stawowej z obawą patrzy w przyszłość, mówiąc: „mniejszość muzułmańska w Indiach powiększa się w zastraszającym tempie. Podejrzewam, iż niebawem, choćby w 2030 roku będziemy mogli mówić o większości". Inny badany z kolei wskazuje, iż społeczność muzułmańska nie przestrzega niepisanej zasady ograniczania potomstwa oraz święcącego coraz większe triumfy wśród mieszkańców Indii trendu Single-Child-Family.

Dane statystyczne stanowczo obalają pogląd, iż przyrost naturalny mniejszości muzułmańskiej jest niebezpiecznie wysoki i stale zwiększa się w porównaniu do przyrostu naturalnego społeczności hinduskiej. Faktem jest, iż w latach 60. XX w., w obliczu eksplozji demograficznej w Indiach, największy przyrost ludności odnotowano właśnie wśród społeczności muzułmanów (z $47 \mathrm{mln}$ w 1961 r. do 138 mln w 2001 r.). Średni wzrost populacji wyniósł wówczas $134 \%$ dla całego społeczeństwa, dla muzułmanów zaś $194 \%$. W stosunku do innych grup religijnych, ich udział w społeczeństwie zwiększył się z 10,7\% w 1961 r. do 13,4\% w 2001 r. ${ }^{41}$, co nierzadko wykorzystywane jest przez hinduskich nacjonalistów do szerzenia propagandy o muzułmanach „zalewających” Indie czy „muzułmańskiej bombie demograficznej”. Na podstawie spisu ludności w 2011 r. ${ }^{42}$ okazuje się jednak, że wskaźnik ten uległ znacznemu obniżeniu. Pomiędzy 2001 a 2011 rokiem przyrost ludności hinduskiej wynosił 16,76\%, a muzułmańskiej 24,6\%. Następnie zmieniał się następująco 19,92\% w przypadku społeczności hinduskiej oraz 29,52\% muzułmańskiej. Wniosek płynący z tych danych jest następujący. Przyrost naturalny muzułmanów wciąż pozostaje proporcjonalnie wyższy niż przyrost hindusów, jednak różnica pomiędzy nimi maleje, a z prognoz wynika, iż wskaźniki te wkrótce ulegną zrównaniu. Jest to wynik zyskującego z Indiach trendu ograniczania potomstwa oraz świadomego planowania rodziny, które obejmuje również społeczność muzułmańską. Zgodnie z prognozą profesora Rama Puniyani z Indian Institute of Technology w Mumbaju:

„Przyrost naturalny wśród muzułmanów będzie wciąż malał aż zrówna się z przyrostem populacji hindusów (...) Co ciekawe, wzrost po-

41 Prime Minister's High Level Committee Cabinet Secretariat Government of India Social, Economic and Educational Status of the Muslim Community of India, November 2006, s. 28-29, http://iamc.com/reports/2006/pmhlc.muslims.pdf [dostęp: 20.07.2018].

42 Office of the Registrar General \& Census Commissioner, India, C-1 Population By Religious Community, http://www.censusindia.gov.in/2011census/c-01.html [dostęp: 20.07.2018]. 
pulacji hinduskiej w latach 2001-2011 wyniósł 133 mln (sic!), co jest wartością zbliżoną do całkowitej liczby muzułmanów w 2001 roku. Straszak w postaci wzbierającej fali muzułmanów, mających rzekomo zdominować społeczeństwo indyjskie, obecny na ustach wielu polityków, w kampaniach i mediach społecznościowych mija się z prawdą. Nie istnieją żadne dane statystyczne na poparcie tej tezy (...)"43.

\section{Zakończenie}

Zarówno konflikt, jak i pokojowe współistnienie społeczności hinduskiej i muzułmańskiej ma w Indiach długą historię. Jest ona naznaczona licznymi podbojami, konfliktami religijnymi oraz rywalizacją polityczną. Jednakowoż stosunki te nierzadko przybierały także formę koegzystencji, intensywnej współpracy handlowej oraz bliskich stosunków sąsiedzkich.

Współczesną emanacją konfliktu hindusko-muzułmańskiego był podział Indii Brytyjskich, który spowodował eksplozję inspirowanej religijnie wrogości i niekontrolowanej przemocy. Gwałtownie ujawniły się wówczas tendencje nacjonalistyczne, jak i komunalistyczne w Indiach. Wydarzenia te stanowiły zarzewie trwającego do dziś konfliktu hindusko-muzułmańskiego. Od czasu podziału w 1947 roku konflikt hindusko-muzułmański zmienił nieco swoje oblicze. W niepodległych Indiach wszyscy gracze polityczni uciekają się do przemocy wyrosłej na różnicach religijnych, etnicznych czy kastowych.

Pierwszą zasadniczą konkluzją płynącą z badań terenowych są względnie dobre stosunki łączące obie społeczności w badanych przeze mnie wioskach. Obie grupy dążą jednak do zachowania odrębności i kultywowania swej religii. Znaczące różnice, które sami respondenci opisują jako kluczowe dla funkcjonowania ich kultury, objawiają się zarówno w sferze diety, jak i higieny osobistej. Kością niezgody pomiędzy społecznościami pozostaje wysoki zarówno rzeczywisty, jak i wyobrażony przyrost naturalny społeczności muzułmańskiej budzący niepokój społeczności hinduskiej. Najczęściej powtarzający się stereotyp obecny w percepcji hin-

43 R. Puniyani, Communalising Population Growth: Understanding Demographic Data, tłum. własne, 2.03.2017, https://countercurrents.org/2017/03/02/communalising-population-growth-understanding-demographic-data/ [dostęp: 20.07.2018]. 
duskiej to z jednej strony ciężko pracujący, uczciwy, lojalny, z drugiej zaś wyznający wartości skrajnie konserwatywne muzułmanin o niskim poziomie wykształcenia i wywodzący się z wielodzietnej rodziny. Warto jednak zaznaczyć, iż wnioski te nie są reprezentatywne dla całego społeczeństwa indyjskiego, gdyż badaniem został objęty jedynie jego ułamek. Przeprowadzone badania miały na celu poszerzenie materiału źródłowego dotyczącego studiów nad tym zagadnieniem.

\section{Bibliografia}

Akbar M.J., Riot after Riot. Reports on Caste and Communal Violence in India, New Delhi 2003, s. 15.

Anderson P., After Nehru, „London Review of Books” 2012, 34:15.

Basu T., Datta P., Sarkar S., Sarkar T., Sen S., Khaki shorts saffron flags, New Delhi 1993.

Berzin A., Part I: The Umayyad Caliphate (661-750 CE), The First Muslim Incursion into the Indian Subcontinent, The Historical Interaction between the Buddhist and Islamic Cultures before the Mongol Empire, https://studybuddhism.com/en/advanced-studies/history-culture/ buddhism-islam-advanced/buddhist-muslim-interaction-umayyadcaliphate/first-muslim-incursion-into-the-indian-subcontinent\#n5.

Bharadwaj P., Khwaja A., Mian A., The Big March: Migratory Flows after the Partition of India, „Economic \& Political Weekly”, No. 43, s. 1, https://sites.hks.harvard.edu/fs/akhwaja/papers/Big\%20March\%20 EPW\%20Publish08.pdf.

Chakrabarty B., Indian Politics and Society Since Independence, Nowy Jork 2008.

Chandra S., Medieval India from Sultanat to Mughals: 1206-1526 Part 1, 1997.

Chopra V.D., Religious Fundamentalism in Asia, New Delhi 1994.

Hardy P., The Muslims of British India, Cambridge 1972.

Hasan M., Adjustment and Accommodation: Indian Muslims after Partition, „Social Scientist” 1990, Vol. 18, No. 8/9. Jaffrelot C., The Hindu Nationalist Movement and Indian Politics, 1996. 
Khan S.S., Sen R., Where Are We Going? Perspective on Hindu-Muslim Relations in India, [w:] Peace Psychology in Asia, red. N. Noor, C.J. Montiel, 2009.

Lament P., M. Zobeniak, Indie - Pakistan - Kaszmir, [w:] Indie w XXI wieku, wybrane problemy, red. A. Potyrała, M. Skobrtala, Poznań 2009.

McLeod J., The history of India, Westport 2002.

Nitza A., Kulturowo-społeczna specyfika Indii i Pakistanu a demokracja, [w:] Azja, Afryka: Inność - Odmienność - Różnorodność, red. P. Bachtin, M. Klimiuk, Warszawa 2014.

Office of the Registrar General \& Census Commissioner, India, C-1 Population By Religious Community, http://www.censusindia.gov.in/ 2011census/c-01.html.

Osuchowska K., Relacje hindusko-muzutmańskie w wielokulturowym spoteczeństwie indyjskim, „Wschodnioznawstwo” 2013, nr 7.

Prime Minister's High Level Committee Cabinet Secretariat Government of India Social, Economic and Educational Status of the Muslim Community of India,, November 2006, http://iamc.com/reports/2006/pmhlc.muslims.pdf.

Przemówienie Muḥammada 'Alī Jinnāḥ na zjeździe Ligi Muzułmańskiej, Lahore 1940, tłum. własne, http://www.columbia.edu/itc/mealac/pritchett/00islamlinks/txt_jinnah_lahore_1940.html.

PTI, Chronology of Communal Violence, „Hindustan Times”, 9.11.2011, https://www.hindustantimes.com/india/chronology-of-communal-violence-in-india/story-jJtcgvxFYh5N3jhSw7H4KN.html.

Puniyani R., Communalising Population Growth: Understanding Demographic Data (tłum. własne), 2.03.2017, https://countercurrents. org/2017/03/02/communalising-population-growth-understandingdemographic-data/.

Ramakrishnan V., A legacy of duplicity, „Frontline” 2006, Vol. 23.

Rao B., Between Promises and Performance. A Critique of Nehru's Contribution to Secularismin India, "Journal of Asian and African Studies" 2006, Vol. 41 (4).

Religion Data - Population of Hindu / Muslim / Sikh / Christian - Census 2011 India, www.census2011.co.in. 
Schimmel A., Islam in the Indian Subcontinent, Leiden 1980.

Schweer T., Hinduizm. Powstanie-dzieje-nauka, Warszawa 2003.

Singh A.K., Intergroup relations and social tensions, [w:] Psychology in India: The state-of-the-art, red. J. Pandey, Vol. 2, 1989.

Thursby G.R., Hindu-Muslim Relations in British India: A Study of Controversy, Conflict, and Communal Movements in Northern India 1923-1928, Leiden 1975.

„Time”, 15.02.2003.

Zajączkowski J., Indie w stosunkach międzynarodowych, Warszawa 2007.

\section{Between Conflict and Coexistence: A Case Study of Hindu-Muslim Relations in Rural North-Western India}

\section{Summary}

The Partition of India upset the status quo causing riots, casualties and a colossal wave of migration that sent thousands of Muslims to their new homeland, Pakistan. Despite the mass violence and displacement, around 35 million Muslims eventually stayed in India. The tensed Hindu-Muslim relations in the aftermath of the Partition intensified a long-standing rivalry between the two groups and led to a feeling of insecurity among Muslims. Strained relations among Hindus and Muslims, which stay at the forefront of social concerns in contemporary India, remain a major cause of worry and call for an in-depth analysis. The article focuses on how the Hindu-Muslim relations developed throughout the modern history, especially during the times of the Indian Independence Movement. The goal of my research is to elucidate historical, social and political contexts of Hin$\mathrm{du}-$ Muslim relations in India and to shed a new light on this multifaceted issue. After presenting a historical perspective on Hindu-Muslim relations, the article provides a case study on both communities' attitudes towards each other. Based on two months of fieldwork conducted in Northern villages of India in January and February 2018, I investigate the multiple stereotypes about Muslims prevailing among Hindu rural community. I address a question whether the character of this uneasy relation is closer to coexistence or a hidden conflict.

Keywords: Hindu Muslim Relations, India, conflict, nationalism, communalism 


\section{МежАу конфииктом и сосуществованием: тематическое исслеАование инАУсско-мусумьманских отношений в семьской северо-запаАной ИнАии}

\section{Резюме}

Разделение Индии нарушимо статускво, вызвав беспорядок, жертвы и ко-

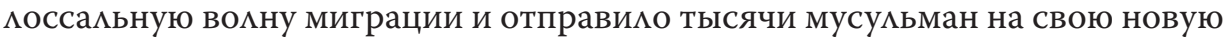
родину в Пакистан. Несмотря на массовое насимие и перемещение, около 35 мимлионов мусульман в конечном итоге остались в Инаии. Нарушенные индусско-мусумьманские отношения, связанные с разделением, усилими Аавнишнее соперничество межАу обоими группами и привели к чувству отсутствия безопасности среАи мусуиьман. Натянутые отношения межАу индусами и мусульманами, которые остаются на переАнем крае социамьных проблем в современной ИнАии, остаются основной причиной беспокойства и требуют углубленного анализа. Статья посвящена тому, как развивались индусско-мусумьманские отношения на протяжении современной истории, особенно во времена Авижения за Независимость ИнАии. Моё исследование объясняет исторический, социальный и политический контекст инаусско-мусумьманских отношений в ИнАии. Это способствует пониманию сложности этого многогранного вопроса. ПреАстав яя рассаАник продолжающейся напряженности в инАуистских мусульманах наряАу исторической перспективой, я предоставАяю тематическое исследование об отношении обоих общин к Аруг Аругу. В статье подчёркнутый практический и повсеАневный аспект индусско-мусумьманских отношений. Я исслеАую множественные стереотипы о мусульманах, преобладающих среАи инаусского семьского сообщества. Я обращаюсь к вопросу, яв яется $и$ әто непростое отношение более как сосуществование ими скрытый конфмикт. Статья основана на Авухмесячных сборах Аанных, проведенных в северных Аеревнях Индии в январе и феврале 2018 года.

Кмючевые слова: инАийские-мусульманские отношения, ИнАия, конфмикт, национакизм, коммунахизм

mgr Natalia Zajączkowska

Wydział Studiów Międzynarodowych i Politologicznych

Uniwersytet Łódzki

ul. Narutowicza 59a

90-131 Łódź

e-mail: n.zajaczkowska@interia.pl 